\title{
Volatile compound profiles and cytotoxicity in essential oils from rhizome of Curcuma aeruginosa and Curcuma zanthorrhiza
}

\author{
RIZKI FITRIA ${ }^{1}$, DJAROT SASONGKO HAMI SENO ${ }^{1}$, BAMBANG PONTJO PRIOSOERYANTO ${ }^{2}$, \\ HARTANTI ${ }^{1}$, WARAS NURCHOLIS ${ }^{1,3, \varphi}$ \\ ${ }^{1}$ Department of Biochemistry, Faculty of Mathematics and Natural Sciences, Institut Pertanian Bogor. Jl. Agatis, Kampus IPB Darmaga, Bogor 16680, \\ West Java, Indonesia. Tel.: +62-251-8423267, ^email: wnurcholis@apps.ipb.ac.id \\ ${ }^{2}$ Department of Veterinary Clinic Reproduction and Pathology, Faculty of Veterinary Medicine, Institut Pertanian Bogor. J1. Agatis, Kampus IPB \\ Darmaga, Bogor 16680, West Java, Indonesia \\ ${ }^{3}$ Tropical Biopharmaca Research Center, Institut Pertanian Bogor. Jl. Taman Kencana No. 3, Bogor 16128, West Java, Indonesia
}

Manuscript received: 8 August 2019. Revision accepted: 15 September 2019.

\begin{abstract}
Fitria R, Seno DSH, Priosoeryanto BP, Hartanti, Nurcholis W. 2019. Volatile compound profiles and cytotoxicity in essential oils from rhizome of Curcuma aeruginosa and Curcuma zanthorrhiza. Biodiversitas 20: 2943-2948. Cancer becomes one of the uncontagious diseases that occupy the top position in the cause of human death under 70 years in the world. Breast cancer is the most widely experienced cancer by women. The aim of this study was to obtain cytotoxic activity essential oil of Curcuma aeruginosa and Curcuma zanthorrhiza as antiproliferative substance of cancer cells and to analyze volatile profile of $C$. aeruginosa and $C$. zanthorrhiza essential oils. The essential oils were obtained from rhizomes of $C$. aeruginosa and $C$. zanthorrhiza by using hydrodistillation method. Volatile compositions of essential oils were analyzed using gas chromatography and mass spectrophotometry (GC/MS). The cytotoxic activities of the essential oil samples were evaluated using brine shrimp lethality test and against MCF-7 (Michigan Cancer Foundation7) and Vero cells. The essential oils of C. aeruginosa, and C. zanthorrhiza showed cytotoxic activities to brine shrimp and MCF-7. Cytotoxic activity presented in essential oil from $C$. aeruginosa and $C$. zanthorrhiza showed lower activity compared with Doxorubicin. The major compounds of $C$. aeruginosa were tropolone (18.1\%), eucalyptol (17.9\%), and curcumol (5.7\%), whereas C. zanthorrhiza were xanthorrhizol (26.8\%), $\beta$-curcumene (17.0\%), ar-curcumene (15.0\%), and germacrone (5.4\%).
\end{abstract}

Keywords: Anticancer, Curcuma aeruginosa, Curcuma zanthorrhiza, essential oils, GC-MS

\section{INTRODUCTION}

Cancer is a non-communicable disease that has been widely spread in the world and leading the main cause of death for under 70 years old human in 91 of 172 countries (WHO 2018). This ailment is caused by a control mechanisms failure of the cell growth and proliferation that can be triggered by a number of factors such as genetic damage, mutations, exposure to carcinogens, chemical and ultraviolet radiation (Lodish 2004). As many as 18.1 million new cases of cancer occurred in 2018 with 9.6 million deaths mortality and 8.6 million of them happened among woman with the most suffered cancer was breast cancer $(24.2 \%)$ (Bray et al. 2018). Breast cancer comes from excessive ductal proliferation which develops into benign tumors then becomes malignant and can metastasize if continuously exposed to cancer-causing agents (Sonnenschein 2016).

Some attempts that commonly used for cancer treatment therapies are surgery, radiation therapy, and chemotherapy. These methods aim to destroy cancer cells and control the growth of tumors in the breast tissue affected by cancer as well as controlling tumor growth on other tissues that are not affected by cancer (Bruton et al. 2005). Nevertheless, these treatments also have side risk effects that damage normal cell metabolism (Uzuner 2012). Therefore, the herbal materials can be a good option in the treatment of cancer due to the least side effects posed by herbal materials than side effects of chemical drugs (Nageh et al. 2018). In addition, the medicines derived from herbal materials are easily obtained (Nugrahaningtyas et al. 2005).

Pharmaceutical properties of herbal materials are found in essential oils. Essential oil is hydrophobic thus can interact with cell membrane and intracellular components cells or even interfere to damage the cells or even to slay the cells (Cristani et al. 2007). The genus Curcuma L (Zingiberaceae) represents a group of perennial rhizoma growing in tropical and subtropical regions such as Asia, Australia and South America (Ravindran et al. 2007). Estimated 93-100 of Curcuma species are widely spread. Curcuma is commonly used for the flavoring and coloring agent of Asian cuisine, traditional medicine, spices, dyes, perfumes, cosmetics, and ornamental plants (Chuakul et al. 2003). Some species of Curcuma have been widely used as medicine to treat bronchial complaints, pneumonia, diarrhea, leucorrhea, dysentery, infectious wounds or abscesses, and insect bites (Basaka et al. 2010). Genus Curcuma that widely found in Indonesia is Curcuma aeruginosa Roxb and Curcuma zanthorrhiza Roxb. $C$. aeruginosa and $C$. zanthorrhiza have a rhizome enriched with essential oil. Some research suggests that essential oils of these herbs contain terpenoids compounds (monoterpenoids and sesquiterpenoids) (Itokawa et al. 2008). C. aeruginosa both its extract and essential oil have 
pharmacological activity. $70 \%$ ethanol extract of this plant had secondary metabolites compound that might inhibit the proliferation of cancer cells such as eucalyptol, $\beta$-elemene, camphor and isocurcumenol (Nurcholis et al. 2017). Essential oil of $C$. aeruginosa had antimicrobial activity against Bacillus cereus, Staphylococcus aureus, Escherichia coli, and Pseudomonas aeruginosa (Kamazeri 2012) and potent antibacterial activity against Enterococcus faecalis (MIC, Minimum Inhibitory Concentration $=6.25 \mu \mathrm{g} / \mathrm{mL})$ and Streptococcus mutans (MIC $=15.63 \mu \mathrm{g} / \mathrm{mL}$ ) (Theanphong et al. 2015; Wahyuni et al. 2017). The oil also showed strong radical-scavenging power evaluated by DPPH scavenging assay $\left(\mathrm{EC}_{50}\right.$, Efficiency Concentration $=24.32 \mu \mathrm{g} / \mathrm{mL}$ ) due to the presence of germacrone and curzerenone (Theanphong et al. 2015). Other pharmacological activities of this oil were as antiandrogenic, antinociceptive, anti-inflammatory and antifungal (Candida albicans, MIC $=250 \mu \mathrm{g} / \mathrm{mL}$ ) (Srivilai et al. 2018; Reanmongkol et al. 2006; Akarchariya et al. 2017). C. zanthorrhiza commonly known as Temulawak contains peculiar metabolite volatile compound Xanthorrhizol. Both extract and essential oil also showed pharmacological activity. Ethyl acetate extract of $C$. zanthorrhiza was able to inhibit the proliferation of MCF-7 cancer cells with $\mathrm{IC}_{50}$ (Inhibitory Concentration) value 1.17 $\mu \mathrm{g} / \mathrm{mL}$ (Ngawi accession) and $6.83 \mu \mathrm{g} / \mathrm{mL}$ (Sukabumi accession) (Nurcholis et al. 2018). Biological activity of $C$. zanthorrhiza including as hepatoprotective and antinociceptive activities (Hartiwi et al. 2014). This oil effectively inhibited copper-mediated oxidation of LDL in thiobarbituric acid reactive substances assay $\left(\mathrm{IC}_{50}=2.2 \pm\right.$ $0.1 \mu \mathrm{g} / \mathrm{mL}$ ) (Jantan et al. 2012) and also showed some pharmacological activities such as antibacterial against S.aureus (ZOI, Zone of Influence $=11.53 \pm 0.27 \mu \mathrm{g} / \mathrm{mL}$ ), antifungal against Candida albicans $(\mathrm{ZOI}=7.29 \pm 0.17$ $\mu \mathrm{g} / \mathrm{mL}$ ) (Akarchariya et al. 2017), antiproliferative, antiinflammatory, antidiuretic, antioxidant, antihyperlipidemic, antiobesogenic and larvicidal (Ozaki 1990; Yasni et al. 1994; Sukari et al. 2007; Schmidt et al. 2015; Salleh et al. 2016).

To the best of our knowledge, cytotoxic potential and antiproliferative activity essential oil of $C$. aeruginosa and C. zanthorrhiza against larva shrimp and MCF-7 breast cancer cells in vitro have not been investigated previously. Therefore, the present study was focussed on understanding $C$. aeruginosa and $C$. zanthorrhiza essential oil as antiproliferative substance and to figure out its volatile compound.

\section{MATERIALS AND METHODS}

\section{Plants materials}

Samples of $C$. aeruginosa and $C$. zanthorrhiza (rhizome) were collected from Biofarmaka Conservation Units, Biofarmaka Tropika Research Center with latitude (S) 6 34'37.95", longitude 106 47'20.37" and altitude (m) 238, Bogor, Indonesia on July 2018.

\section{Distillation of essential oil}

Extraction of $C$. aeruginosa and $C$. zanthorrhiza essential oils were carried out using steam distillation. Total of $3000 \mathrm{~g}$ of the sliced samples was inserted into the distillation container and added water by ratio of $1: 5$ (sample: water) then heated to a temperature $100-105{ }^{\circ} \mathrm{C}$ for 4 hours. The essential oil produced then stored on $4{ }^{\circ} \mathrm{C}$. Percent yield of essential oil obtained was calculated according to the following equation:

$$
\% \text { Yield }=\frac{\text { oil weight }}{\text { dry sample weight }} \times 100 \%
$$

\section{Essential oil cytotoxicity test with Brine Shrimp Lethality Test (BSLT)}

The larvae egg of Artemia salina Leach were hatched on beaker glass contained seawater and aerator for 24 hours in case to alter it into larva. Essential oil solutions were made by dissolving it using seawater and tween 80 into concentration $1000,500,100,10 \mu \mathrm{g} / \mathrm{mL}$ and $0 \mu \mathrm{g} / \mathrm{mL}$ (control). After 24 hours, a set of test plate containing 10 shrimp larvae, $1 \mathrm{~mL}$ seawater and $0.5 \mathrm{~mL}$ essential oil solution with each concentration was incubated for 24 hours then the number of dead larvae was calculated. The control was treated similarly except without the granting of essential oils. $\mathrm{LC}_{50}$ (Lethality Concentration) values were determined by using probit analysis SPSS 16.0.

\section{Antiproliferative test of essential oils against MCF-7 cancer cells}

Complete growing mediums containing $850 \mu \mathrm{L}$ Dulbecco's Modified Eagle's Medium (DMEM), $10 \mu \mathrm{L}$ gentamicin (antibiotic), $10 \mu \mathrm{L}$ fungizone and $30 \mu \mathrm{L}$ Fetal Calf Serum (FCS) were made for each MCF-7 and Vero cells line. Essential oil solutions were made with concentrations $30,65,100,135$ and $170 \mu \mathrm{g} / \mathrm{mL}$ and 0 $\mu \mathrm{g} / \mathrm{mL}$ (controls) using DMSO $10 \%$ as solvent. Cell cultures then were made on 24 microplates which contained complete growing medium and essential oil solutions with 5 different concentrations. Positive control using doxorubicin and without the granting of essential oils as negative controls. $50 \mu \mathrm{L}$ cell suspensions were inserted into each well triple. The cells culture then incubated inside the incubator at a temperature of $37{ }^{\circ} \mathrm{C}\left(5 \% \mathrm{CO}_{2}\right)$.

After confluence about 3 days, the cells then harvested and counted. The calculation was conducted using a microscope with 100 times magnification. A total of 100 $\mu \mathrm{L}$ of cells suspension was homogenized in a microplate that had contained $5 \mu \mathrm{L}$ trypan blue and $10 \mu \mathrm{L}$ of homogenized cells suspension were placed in the hemocytometer and calculated the total number of cells. The percentage of percent inhibition activity was determined as follows:

$\%$ Inhibition activity $=100 \%-\left(\frac{\text { treatment cell number }}{\text { negative cells number }} \times 100 \%\right)$ 


\section{GC-MS analysis}

Analysis of volatile compounds contained in essential oil of each plant by using Agilent Technologies GC-MS machine with mass selective detector. $20 \mu \mathrm{L}$ of essential oils were dissolved into $2000 \mu \mathrm{L}$ dichloromethane (1:100 $\mathrm{v} / \mathrm{v})$. The samples were separated using capillary column HP INNOWAX ( $30 \mathrm{~m} \times 0.25 \mathrm{~mm}, 0.25 \mu \mathrm{m}$ thickness) with helium as carrier gas $(0.6 \mathrm{~mL} /$ minute). Initial temperature for analysis was $60{ }^{\circ} \mathrm{C}$ raised to $150{ }^{\circ} \mathrm{C}$ and with the rise of $2{ }^{\circ} \mathrm{C}$ /min for about 1 minute then increased to $210{ }^{\circ} \mathrm{C}$ with the rate increase $20{ }^{\circ} \mathrm{C} /$ minute and maintained constant for 10 minutes. Separation rate ratios were 250:1. The temperature when the injection was $150{ }^{\circ} \mathrm{C}$ for $1 \mu \mathrm{L}$ essential oil.

\section{Data analysis}

Statistical analysis using SPSS 16.0 probit analysis to measure the value of $\mathrm{LC}_{50}$. Counted the $\mathrm{IC}_{50}$ value of cells inhibition by using linear regression analysis and Duncan test to find out the significant difference between samples.

\section{RESULTS AND DISCUSSION}

The yield of essential oils produced from distillation process was not plenty. This was due to several factors such as the condition of the material and the distillation time. Wither material will produce more yield of essential oil compared to fresh material because moisture content in the gland of the material had been reduced and the extraction was easier to do. Longer distillation times will result in more essential oil yields since the volatile compounds that are hard to evaporate will require longer heating time to evaporate, in addition, growing land and soil conditions also affect the yield of essential oils (Cassel and Vargas 2013). Distillation process obtained the volume of essential oils produced by each plant that presented in Table 1.

Preliminary test (BSLT) was conducted to find out the cytotoxicity of essential oils and declared as $\mathrm{LC}_{50}$, the minimum concentration required to kill $50 \%$ of the population. An extract allegedly to have cytotoxic potential if it $\mathrm{LC}_{50}$ value is less than $1000 \mu \mathrm{g} / \mathrm{mL}$ (Meyer et al. 1982). All essential oils from tested plants had a toxic potential because it had a $\mathrm{LC}_{50}$ value below $1000 \mu \mathrm{g} / \mathrm{mL}$ $(78,2$ and $83.6 \mu \mathrm{g} / \mathrm{mL}$ for $C$. aeruginosa and $C$. zanthorrhiza respectively). Essential oils cytotoxicity was defined in $\mathrm{LC}_{50}$ (Table 2). The BSLT test results showed that all plants had toxic potentials thus also had potential as antiproliferative substance against MCF-7 cells.

Essential oil antiproliferative test against MCF-7 cancer cells are shown in Table 3. C. zanthorrhiza essential oil showed the most excellent inhibitory against MCF-7 cells $\left(\mathrm{IC}_{50}, 139.8 \mu \mathrm{g} / \mathrm{mL}\right.$ ) followed by $C$. aeruginosa. Antiproliferation activity of essential oils tested against MCF-7 cancer cells by using the total cells method according to Priosoeryanto et al. (1994) with the principle of negative control in the microplate containing cancer cells and growth media is considered to proliferate by $100 \%$ thereby the total treatment cells (given essential oils) as well as positive control (doxorubicin) will be compared to the total cells on the negative control and percent proliferation as well as percent inhibition can be obtained. Cells were incubated in incubator for 3 to 4 days because it takes 3-4 days for cells to grow and proliferate optimally. Less than 3 days the cells have not grown optimally and more than 4 days the cells will suffer death due to the lack of growth nutrients. The total cells count was performed with the hemocytometer under the microscope with magnification 100 times with trypan blue to clarify the display of cells under the microscope.

Results showed that cancer cells proliferation decrease as the concentration of the extract given increase. The biggest concentration in each essential oil of $C$. aeruginosa and C. zanthorrhiza were capable of inhibiting $50.2 \%$ and $59.1 \%$ of MCF-7 cancer cells in vitro respectively (Figure 1). N-hexane fraction of $C$. aeruginosa had potential as an antiproliferation against the MCF-7 cancer cells with $\mathrm{IC}_{50}$ value $69.5 \mu \mathrm{g} / \mathrm{mL}$ (Sriatun et al. 2016), thus proved that $C$. aeruginosa as volatile metabolite compounds as well as extracts can be functioned as antiproliferative cancer cells compound. Then $C$. zanthorrhiza essential oil was able to inhibit the growth of YBM-1 cancer cells with $\mathrm{IC}_{50}$ value $2.9 \mu \mathrm{g} / \mathrm{mL}$ (Udin 2013).

Test against Vero normal cells was also conducted to determine the effect of essential oils granting of these plants to normal cells proliferation. Figure 2 shows that essential oils of $C$. aeruginosa and $C$. zanthorrhiza do not interfere with normal cell proliferation with percent inhibition of $7.5 \%$ and $7.7 \%$ respectively. Inhibition of essential oils against MCF-7 cancer cells and Vero normal cells also compared to the administration of doxorubicin (drug used for cancer treatment) on both cells. Figures 1 and 2 indicate that doxorubicin at concentrations of 100 $\mu \mathrm{g} / \mathrm{mL}$ not only inhibited MCF-7 cells by $65.1 \%$ but also damage the proliferation of Vero normal cells by $35.2 \%$, while $C$. aeruginosa and $C$. zanthorrhiza at equal concentrations only inhibited the proliferation of Vero normal cells by $4.8 \%$ and $7.29 \%$ respectively and thus indicated that essential oils of $C$. aeruginosa and $C$. zanthorrhiza were safer against normal cells compared to doxorubicin.

Table 1. Yield and volume of essential oils distillation

\begin{tabular}{lll}
\hline Plant & Volume $(\mathbf{m L})$ & Yield $(\%)$ \\
\hline C. aeruginosa & 1 & 0.03 \\
C. zanthorrhiza & 2 & 0.06 \\
\hline
\end{tabular}

Table 2. Plant essential oil cytotoxicity against $A$. salina

\begin{tabular}{ll}
\hline Plant & LC $_{\mathbf{5 0}}(\boldsymbol{\mu g} / \mathbf{m L})$ \\
\hline C. aeruginosa & $78.2 \pm 7.3$ \\
C. zanthorrhiza & $83.6 \pm 12.1$ \\
\hline
\end{tabular}

Table 3. $\mathrm{IC}_{50}$ essential oils of each plant against MCF-7 cell

\begin{tabular}{ll}
\hline Plant & IC $_{\mathbf{5 0}}(\mu \mathrm{g} / \mathbf{m L})$ \\
\hline C. aeruginosa & 161.0 \\
C. zanthorrhiza & 139.8 \\
\hline
\end{tabular}




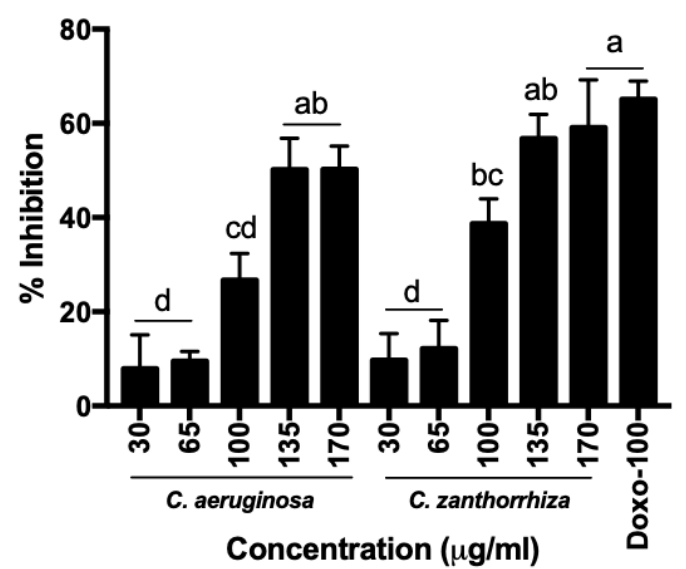

Figure 1. Inhibition graph of $C$. aeruginosa and C. zanthorrhiza essential oil against proliferation of MCF-7 cells line. Value followed by the same letters indicates they are not significantly different by Duncan test at $\mathrm{p} \leq 0.05$. Doxo $=$ doxorubicin.

Table 4. Major volatile compound of each plant identified using GC-MS analysis

\begin{tabular}{|c|c|c|c|}
\hline \multirow{2}{*}{$\begin{array}{c}\text { Retention } \\
\text { time (Min) }\end{array}$} & \multirow{2}{*}{$\begin{array}{c}\text { Library } \\
\text { identification }\end{array}$} & \multicolumn{2}{|c|}{ Peak area $(\%)$} \\
\hline & & $\begin{array}{c}C . \\
\text { aerruginosa }\end{array}$ & $\begin{array}{c}C . \\
\text { zanthorrhiza }\end{array}$ \\
\hline 3.84 & Toluene & 4.78 & - \\
\hline 7.31 & Eucalyptol & 17.90 & 0.35 \\
\hline 20.33 & Camphor & 5.31 & 9.06 \\
\hline 49.92 & Tropolone & 18.07 & - \\
\hline 51,27 & Curcumol & 5.69 & - \\
\hline 51.35 & $\begin{array}{l}(\mathrm{Z}, \mathrm{Z})-\mathrm{3}, 6- \\
\text { Nonadienal }\end{array}$ & 3.86 & - \\
\hline 21.97 & $\begin{array}{l}\text { alpha- } \\
\text { Curcumene }\end{array}$ & - & 15.05 \\
\hline 22.46 & Curzerene & - & 3.90 \\
\hline 23.11 & $\begin{array}{l}\text { beta- } \\
\text { Curcumene }\end{array}$ & - & 17.04 \\
\hline 24.64 & Germacrene B & - & 2.08 \\
\hline 26.10 & Epicurzerenone & - & 5.97 \\
\hline 27.61 & Germacrone & - & 5.43 \\
\hline 28.61 & Xanthorrhizol & - & 26.77 \\
\hline
\end{tabular}

Volatile compounds from GC-MS results of the plants acquired a total of 38 compounds identified. Major compounds in $C$. aeruginosa were 5 compounds: eucalyptol (17.90\%), camphor (5.31\%), tropolone $(18.07 \%)$, curcumol $(5.69 \%)$ and $(\mathrm{Z}, \mathrm{Z})-3.6$-nonadienal (3.86\%) while major compounds found in $C$. zanthorrhiza were 8 compounds: camphor $(9.06 \%)$, alpha-curcumene $(15.05 \%)$, curzerene $(3.90 \%)$, beta-curcumene $(17.04 \%)$, germacrene B (2.08\%), epicurzerenone (5.97\%), germacrone $(5.43 \%)$, and xanthorrhizol $(26.77 \%)$. GC-MS chromatogram showed that mostly terpenoid (monoterpenoid and sesquiterpenoid) group were the major volatile compound contained in essential oil of each plant (Table 4).

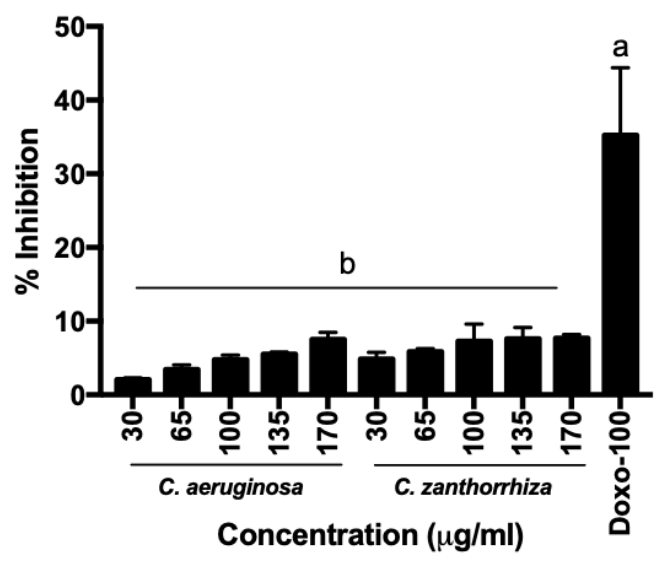

Figure 2. Inhibition graph of $C$. aeruginosa and $C$. zanthorrhiza's essential oil against proliferation of Vero normal cells line. Value followed by the same letters indicates they are not significantly different by Duncan test at $\mathrm{p} \leq 0.05$. Doxo $=$ doxorubicin.

GC-MS chromatogram analysis showed that major compounds of the plants were terpenoid group (monoterpenoid and sesquiterpenoid). Terpenoids are one of the secondary metabolites compounds which are widely produced by plants, especially in its vacuoles. Terpenoids are contained in the essential oil of plants. Terpenoids are compounds with a large structure constructed from units of isoprene (C5). Isoprene is derived from metabolism of acetic acid through the mevalonic acid (MVA) line (Sukadan 2008). Total of volatile compounds identified in GC-MS analysis were 38 compounds, but only 13 major compounds identified with peak area greater than $2 \%$. Among those 13 major compounds, 9 compounds were allegedly played role as antiproliferative compound (Table 4).

Tropolone was a compound contained in C. aeruginosa that was suspected to inhibit the proliferation of cancer cells. Tropolone and its derivatives were great to inhibit several cancer cells such as HCT-116 (colon cancer), BXPC-3 (pancreatic cancer), Jurkat (leukemia) and HuT78 (T-lymphocytes) with Growth Inhibitory value $\left(\mathrm{GI}_{50}\right)$ ranges between 5 and $30 \mu \mathrm{M}$. It had a good selectivity for normal cell hDf (Human Dermal Fibroblasts cell) with $\mathrm{GI}_{50}$ value $95 \mu \mathrm{M}$ (Ononye 2013). Tropolone was suspected to inhibit proliferation of cancer cells by inhibiting Histon Deacetylase (HDAC), an enzyme that plays a role in several biochemical processes such as transcription regulation, tubulin regulation and cytoskeletal function, controlling cardiac growth, thymocyte development regulations and facilitating DNA repair (Huangfu et al. 2008; Granger et al. 2008; Ouaissi et al. 2011; Estiu et al. 2010; Somoza et al. 2004). Some epigenetic pathways related to cancer, one of them is acetylated gene controlled by Histon Acetyltransferases and Histon Deacetylase which regulates gene expression and chromatin structure. Histone deacetylase inhibitors become a new target in anticancer therapy by reactivating tumor suppressor gene (Goswami et al. 2018). By inhibiting HDAC it will inhibit cell growth and induce cell differentiation (Lemoine and Younes 
2010). Another most prevalent volatile metabolites found in $C$. aeruginosa was eucalyptol. 1,8-cineole, which is another name of eucalyptol, was able to inhibit the growth of HL-60 cancer cells (human leukemia) by inducing apoptosis process (Moteki et al. 2002). Eucalyptol can activate survivin (an apoptosis protein inhibitor that lowers the apoptosis process) and Akt pathway/phosphatidylinositol-3-kinase (PI3K) (cell signaling pathway that promotes cell growth and will be the target of apoptosis) as well as activating the P38 MAP kinase (part of the MAP kinase family that is activated by cellular stress and causes apoptosis). Eucalyptol also induced the cutting of Poly ADP ribose polymerase (PARP) and caspase-3 thereby causing apoptosis (Murata et al. 2013). Eucalyptol/1, 8-cineole was also supposed to have a role in suppressing the proliferation of MCF-7 cancer cells due to its abundance in $C$. aeruginosa. Curcumol had been widely reported to have potential as antiproliferation of cancer cell. Granting of curcumol in MDA-MB cancer cells (breast cancer) was able to inhibit the proliferation of cells with $\mathrm{IC}_{50}$ value $100.2 \mu \mathrm{g} / \mathrm{mL}$ by arresting cell in G1 phase and triggering apoptosis through mitochondrial pathway (Huang et al. 2017). Other compounds that were also identified in C. aeruginosa were camphor. According to Itani et al. (2008), camphor was able to inhibit cell cycles and induced apoptosis via mitochondrial pathway in HCT-116 cells in in vitro by $30 \%$ then stopped the cell proliferation. Choudhury et al. (2018) explain that cancer cells were able to avoid apoptosis process by over-activation of anti-apoptosis genes and deregulation pro-apoptosis gene. B-cell lymphoma 2 (BCL-2) is an important member in regulating death and survival of cells. BCL-Xl is an anti-apoptosis protein. P53 which is a Tumor suppressor protein confers control over cell cycle and apoptosis. Camphor allegedly led to up-regulation of p53 thereby lowering the antiapoptosis protein (BCL-Xl) levels and raising proapoptosis protein (Bax) levels.

Peculiar volatile metabolites contained in $C$. zanthorrhiza is xanthorrhizol which had the potential as antiproliferation substance of cancer cells. Xanthorrhizol was able to inhibit the proliferation of MDA-MB (breast cancer) cells with $\mathrm{GI}_{50}$ value $8.67 \mu \mathrm{g} / \mathrm{mL}$ by triggering apoptosis through mitochondrial pathways (Cheah et al. 2008) as well as inhibiting the proliferation of MCF-7 cancer cells with Effectivity Concentration value $\left(\mathrm{EC}_{50}\right)$ $1.71 \mu \mathrm{g} / \mathrm{mL}$ by apoptosis induction through modulation of BCL-2, p53 and PARP-1 protein (Cheah et al. 2006). Xanthorrhizol was also able to decrease the proliferation of HeLa cells (cervical cancer) with $\mathrm{EC}_{50}$ value $6.16 \mu \mathrm{g} / \mathrm{mL}$ through up-regulation of tumor suppressor proteins p53 and Bax apoptosis pro proteins. Beta-curcumene and Arcurcumene contained in $C$. zanthorrhiza also reported being an anti-proliferation compound for cancer cells. Curcumene causing apoptosis in cancer cells through mitochondrial pathway that secreted the cytochrome $\mathrm{C}$ and activates the caspase resulting in cell apoptosis (Shin and Lee 2013). Germacrone was a potential anti-proliferation compound of cancer cells. The provision of germacrone in MDA-MB cells lowered the viability of the cell through apoptosis mitochondrial pathway and arrested the cell cycle in the G0/G1 and G2/M phases by decreasing retinoblastoma protein suppressor tumor $(\mathrm{Rb})$ which plays a role in regulation of cell proliferation, lowering cyclindependent kinases (CDK-2) thus preventing cells from entering the mitosis phase as well as lowering total phosphorylation of CDK-2 (Zhong et al. 2011). Another volatile metabolite compound on $C$. zanthorrhiza potentially as antiproliferation substance was curzerene. According to Wang et al. (2016), curzerene was able to inhibit the proliferation of SPC-A1 (lung cancer) cells with an $\mathrm{IC}_{50}$ value $47 \mu \mathrm{M}$ by arresting cell in the $\mathrm{G} 2 / \mathrm{M}$ phase and triggering cell apoptosis. Curzerene was able to lower the expression of GSTA1 proteins and mRNA expressions in SPC-A1 cells.

The abundance of volatile compounds contained in $C$. aeruginosa and C.zanthorrhiza essential oil that is supposedly potential to inhibit the proliferation of cancer cells, resulting in its necessity to explore further the potential of these plants.

\section{ACKNOWLEDGEMENTS}

This study was supported by the Ministry of Finance Republic of Indonesia and the Ministry of Research, Technology and Higher Education of the Republic of Indonesia with grant no. 4324/IT3.L1/PN/2019.

\section{REFERENCES}

Akarchariya N, Sirilun S, Julsrigival J, Chansakaowa S. 2017. Chemical profiling and antimicrobial activity of essential oil from Curcuma aeruginosa Roxb., Curcuma glans K. Larsen and Curcuma cf. xanthorrhiza Roxb. collected in Thailand. Asian Pac J Trop Biomed 7: 881-885

Basaka S, Sarma GC, Rangan L. 2010. Ethnomedical uses of Zingiberaceous plants of Northeast India. J Ethnopharmacol 132: 286-296.

Bray F, Ferlay J, Soerjomataram I, Siegel RL, Torre LA, Jemal A. 2018. Global cancer statistics 2018: Globocan estimates of incidence and mortality worldwide for 36 cancers in 185 countries. Cancer J Clin 68: 394-424.

Bruton L, Lazo JS, Parker KL. 2005. Goodman \& Gilman's The Pharmacological Basis of Therapeutics 11th Ed. Mc Graw Hill, Lange, New York.

Cassel E, Vargas R. 2013. Experiments and modelling of the Cymbopogon nardus essential oil extraction by steam distillation. J Mex Chem Soc 50: 126-129.

Cheah YH, Azimahtol HL, Abdullah NR. 2006. Xanthorrhizol exhibits antiproliferative activity on MCF-7 breast cancer cells via apoptosis induction. Anticancer Res 26: 4527-34.

Cheah YH, Nordin FJ, Tee TT, Azimahtol HL, Abdullah NR, Ismail Z. 2008. Antiproliferative property and apoptotic effect of xanthorrhizol on MDA-MB-231 breast cancer cells. Anticancer Res 28: 3677-89.

Choudhury, Kandimalla R, Elancheran R, Bharali R, Kotoky J. 2018. Garcinia morella fruit, a promising source of antioxidant and antiinflammatory agents induces breast cancer cell death via triggering apoptotic pathway. Biomed Pharm 103: 562-573.

Chuakul W, Boonpleng A. 2003. Ethnomedical uses of Thai Zingiberaceous plant. Thai J Phytopharm 10: 33-39.

Cristani M, D'arrigo M, Mandalari G, Castelli F, Sarpietro MG, Micieli D. et al. 2007. Interaction of four monoterpenes contained in essential oils with model membranes: implications for their antibacterial activity. J Agric Food Chem 55: 6300-6308 
Estiu G, West N, Mazitschek R. 2010. On the inhibition of histone deacetylase 8. Bioorg Med Chem 18: 4103-10.

Goswami, Kandimalla R, Kalita S, Chattopadhyay A, Ghosh SS. 2018. Polyethylene glycol-encapsulated histone deacetylase inhibitor drugcomposite nanoparticles for combination therapy with artesunate. ACS Omega 3: 11504-11516.

Granger A, Abdullah I, Huebner F. 2008. Histone deacetylase inhibition reduces myocardial ischemia-reperfusion injury in mice. FASEB J 22 : 3549-60.

Hartiwi D, Syah YM, Lia D. 2014. Antibacterial Curcuma xanthorrhiza extract and fractions. J Math Fundam Sci 46: 224-234

Huang L, Li A, Liao G, Yang F, Yang J, Chen X, et al. 2017. Curcumol triggers apoptosis of p53 mutant triple-negative human breast cancer MDA-MB 231 cells via activation of p73 and PUMA. Oncol Lett 14: 1080-1088.

Huangfu D, Maehr R, Guo W. 2008. Induction of pluripotent stem cells by defined factors is greatly improved by small-molecule compounds Nat Biotechnol 26: 795-7.

Itani WS, El-Banna SH, Hassan SB, Larsson RL, Gali AM. 2008. Anticolon cancer components from Lebanese sage (Salvia libanotica) essential oil: mechanistic basis. Cancer Biol Ther 7: 1765-1773.

Itokawa H, Shi Q, Akiyama T, Morris-Natschke SL, Lee KH. 2008 Recent advances in the investigation of Curcuminoids. Chin Med 11: 331-339.

Jantan I, Saputri FC, Qaisar MN, Buang F. 2012. Correlation between chemical composition of Curcuma domestica and Curcuma xanthorrhiza and their antioxidant effect on human low-density lipoprotein oxidation. Altern Med 43: 112-118.

Kamazeri TS. 2012. Antimicrobial activity and essential oils of Curcuma aeruginosa, Curcuma mangga and Zingiber cassumunar from Malaysia. Asian Pac J Trop Med 5: 202-209.

Lemoine M, Younes A. 2010. Histone deacetylase inhibitors in the treatment of lymphoma. Discov Med 10: 462-70.

Lodish H. 2004. Molecular Cell Biology 5th ed. WH Freeman and Co, New York.

Meyer BN, Ferrigni NR, Putnam JE, Jacobsen LB, Nichols DE, McLaughin JL. 1982. Brine shrimp: a convenient general bioassay for active plant constituent. Planta Med 45: 31-34.

Moteki H, Hibasami H, Yamada Y. 2002. Specific induction of apoptosis by 1,8-cineole in two human leukemia cell lines, but not a in human stomach cancer cell line. Oncol Rep 9: 757-760.

Murata S, Shiragami R, Kosugi C, Tezuka T, Yamazaki M, Hirano A. 2013. Antitumor effect of 1,8-cineole against colon cancer. Oncol Rep 30: 2647-52

Nageh AEM, Omar AST, Mohamed F, Mohamed A, Mohammed S. 2018 The potential efficacy of antidepressants and Moringa oleifera in experimentally induced ulcerative colitis in rats. Nat Sci 16: 64-72.

Nugrahaningtyas KKD, Matsjeh S, Wahyuni TD. 2005. Isolasi dan identifikasi senyawa flavonoid dalam rimpang temu ireng (Curcuma aeruginosa Roxb). J Biofarm 3: 32-38. [Indonesian]

Nurcholis W, Khumaida N, Syukur M, Bintang M. 2017. Analisis kemiripan 20 aksesi temu ireng (Curcuma aeruginosa Roxb) berdasarkan warna rimpang, hasil ekstrak dan kandungan fitokimia. J Agron Indonesia 44: 315-321. [Indonesian]

Nurcholis W, Munshif AA, Ambarsari L. 2018. Xanthorrhizol contents, $\alpha$ glucosidase inhibition, and cytotoxic activities in ethyl acetate fraction of Curcuma zanthorrhiza accessions from Indonesia. Braz J Pharmacog 28: 44-49.

Ononye SN. 2013. Towards The Development of Tropolone Natural Product Derivatives As Novel, Potent Anticancer Therapeutics that Selectively Target Histone Deacetylase (HDAC) Enzymes. [Dissertations]. University of Connecticut, Storrs. [United State]

Ouaissi M, Giger U, Sielezneff I. 2011. Rationale for possible targeting of histone signaling in cancer diseases with a special reference to pancreatic cancer. J Biomed Biotechnol 31: 5939.
Ozaki Y. 1990. Antiinflammatory effect of Curcuma xanthorrhiza Roxb and its active principles. Chem Pharm Bull 38: 1045-1048.

Priosoeryanto BP, Tateyama S, Yamaguchi R, Uchida K. 1994. Antiproliferation and colony forming inhibition activities of recombinant Feline Interferon (rFeIFN) on various cells in vitro. Res in Vet Sci 58: 272-276.

Ravindran PN, Babu KN, Shiva KN. 2007. Botany and Crop Improvement of Tumeric: in Tumeric The Genus Curcuma. CRC Press, United State.

Reanmongkol W, Subhadirasakul S, Khaisombat N, Fuengnawakit P, Jantasila S, Khamjun A. 2006. Investigation the antinociceptive, antipyretic and anti-inflammatory activities of Curcuma aeruginosa RoxB extracts in experimental animal. Songklanakarin J Sci Technol 28: $999-1008$

Salleh NM, Ismail S, Halim ABM. 2016. Effects of Curcuma xanthorrhiza extracts and their constituents on phase II drugmetabolizing enzymes activity. Pharmacognosy Res 8: 309-316.

Schmidt E, Ryabchenko B, Wanner J, Jager W, Jirovets L. 2015. Cytotoxic active constituents of essential oils of Curcuma longa and Curcuma zanthorrhiza. Nat Prod Commun 10: 139-141.

Shin Y, Lee Y. 2013. Cytotoxic activity from Curcuma zedoaria through mitochondrial activation on ovarian cancer cells. Tox Res 29: 257-61.

Somoza JR, Skene RJ, Katz BA. 2004. Structural snapshots of human HDAC8 provides insights into the class I histone deacetylases. J Struct 12: 1325-34.

Sonnenschein C, Soto AM. 2016. Carcinogenesis explained within the context of a theory of organisms. Prog Biophy Mol Bio 122: 70-76.

Sriatun, Arianingrum R, Aznam N, Malek SNAb. 2016. Isolation of sesquiterpenes lactone from Curcuma aeruginosa rhizome and the cytotoxic activity against human cancer cell lines. Int J Pharmacog Phytochem 8: 1168-117.

Srivilai J, Waranuch N, Tangsumranjit A, Khorana N, Ingkaninan K. 2018. Germacrone and sesquiterpene-enriched extracts from Curcuma aeruginosa RoxB increase skin penetration of minoxidil, a hair growth promoter. Drug Deliv Transl Res 8: 140-149.

Sukadan IM. 2008. Aktivitas antibakteri golongan triterpenoid dari biji pepaya (Carisa papaya L). ISSN 34: 1907-9850. [Indonesian]

Sukari MAH, Saad SM, Lajis NH, Rahman M, Muse R, Yusuf UK, Riyanto S. 2007. Chemical constituents and bioactivity of Curcuma aeruginosa Roxb. Nat Prod Sci 13: 175-179.

Theanphong O, Mingvanish W, Kirdmanee C. 2015. Chemical constituent and biological activities of essential oil from Curcuma aeruginosa RoxB rhizome. Bull Heal Sci Technol 13: 6-16.

Udin Z. 2013. Cytotoxic activity of xanthorrhizol from Curcuma xanthorrhiza RoxB volatile oil toward YMB-1 breast cancer cell. J Kim Terap Indones 15: 23-29. [Indonesian]

Uzuner H. 2012. Traditional Chinese medicine research in the postgenomic era: good practice, priorities, challenges and opportunities. Jethpharm 140: 458-468.

Wahyuni WT, Batubara I, Tambunan DY. 2017. Antibacterial and teeth biofilm degradation activity of Curcuma aeruginosa essential oil. J Biol Sci 17: 84-90.

Wang Y, Li J, Guo J, Wang Q, Zhu S, Gao S, et al. 2016. Cytotoxic and antitumor effects of Curzerene from Curcuma longa. J Planta Med 75: 324-331.

World Health Organization. 2018. Global Health Observatory. World Health Organization, Geneva. who.int/gho/database/ en/.

Yasni S, Imaizumi K, Sin K, Sugano M, Nonaka G. 1994. Identification of an active principle in essential oils and hexane-soluble fractions of Curcuma xanthorrhiza Roxb. showing triglyceride-lowering action in rats. Food Chem Toxicol 32: 273-278

Zhong Z, Chen X, Tan W, Xu Z, Zhou K, Wu T, et al. 2011. Germacrone inhibits the proliferation of breast cancer cell lines by inducing cell cycle arrest and promoting apoptosis. Eur J Pharmacol 667: 50-5. 